\title{
Formation and reduction of nitrogen oxides in the combustion of fuels in a circulating fluidized bed
}

\author{
V. Munts, Y. Munts, A. Proshin \& V. Khudyakova \\ Ural Federal University, Russia
}

\begin{abstract}
This paper is devoted to the study of the processes of forming and reducing nitrogen oxides in the combustion of fuels in a circulating fluidized bed (CFB). All experimental studies were conducted using special laboratory equipment. To develop a model of the nitrogen oxides formation, the process of fuel combustion in a fluidized bed was split into two stages: the combustion of volatiles and coke residue burning. Nitrogen formation and reduction in combustion with oxygen deficiency are discussed, which is one of the most effective ways of reducing nitrogen oxides emissions in the combustion of the fuel in the CFB.

Keywords: nitrogen oxides, solid fuel, circulating fluidized bed.
\end{abstract}

\section{Introduction}

The process of nitrogen oxides formation in the fluidized bed, supplemented by burning out the particles of solid fuel was studied using the experimental equipment which is an electric furnace with a cylindrical heating chamber the inner diameter of which is $50 \mathrm{~mm}$ and which has an air distribution cap welded into the bottom. Combustion products' composition was constantly being measured using gas analyzers and automated data acquisition and processing systems. Brown Moscow-area coal, Berezovsky coal, Donetsk anthracite, Kuznetsk meagre coal, coke fines breeze of Kuznetsk coal and two slates (Estonian and Volga) were used as a fuel [1].

To make experiments, fuel fractions having particles of $0.8 ; 1.5 ; 2.5 ; 4 ; 6$ and $8.5 \mathrm{~mm}$ sizes were sifted out; samples of small weight $(0.5-2 \mathrm{~g})$ were burned in the fluidized bed at various temperatures. 
The air force flow of the fluidized bed at $900^{\circ} \mathrm{C}$ demonstrated that "thermal" oxides (i.e. nitrogen oxides formed from the air molecular nitrogen by Zeldovitch mechanism [2]) were not being generated under the experimental conditions, so, hereafter, all the nitrogen oxides formed were regarded as "fuel" ones the source of which was fuel nitrogen.

The experimental data shows nitrogen oxides and carbon dioxides formation in the process of burning small weight samples $(0.5 \mathrm{~g})$ from the Moscow-area coal and anthracite. All the coals of high volatiles' content show evidence of the interrelation between changes in the concentrations of $\mathrm{CO}_{2}$ and $\mathrm{NO}_{x}$ : in volatile substances' burning there's a sharp synchronous increase in $C_{\mathrm{NO}}$ and $C_{\mathrm{CO}_{2}}$ concentrations, while at the stage of the coke residue combustion these decrease to zero. In the combustion of low volatiles' content fuels the maximum of $\mathrm{CO}_{2}$ and $\mathrm{NO}_{x}$ concentrations is not so pronounced: nitrogen and carbon oxides are being formed in a more uniform manner. To quantify $\mathrm{CO}_{2}$ and $\mathrm{NO}_{x}$ formation, their atomic weights $m_{\mathrm{NO}_{x}}$ and $m_{\mathrm{CO}_{2}}$ formed by the particular time $\tau$ were calculated:

$$
m_{\mathrm{NO}_{x}}(\tau)=\frac{\int_{0}^{\tau} C_{\mathrm{NO}_{x}} d \tau}{\int_{0}^{\tau_{\mathfrak{\mathrm { a }}}} \tilde{N}_{\mathrm{NO}_{x}} d \tau} ; \quad m_{\mathrm{CO}_{2}}(\tau)=\frac{\int_{0}^{\tau} \tilde{N}_{\mathrm{CO}_{2}} d \tau}{\int_{0}^{\tau_{\mathfrak{\mathrm { a }}}} \tilde{N}_{\mathrm{CO}_{2}} d \tau},
$$

where $\tau_{\Gamma}$ is the complete time period of the fuel sample burning out experimentally found.

The formation of nitrogen oxides as compared to those of $\mathrm{CO}_{2}$ is of greater intensity at the stage of volatile substances combustion. The quantitative parameter enabling this intensity to be evaluated is the nitrogen oxides' relative fraction $\varphi_{N}$ released during the time of visible volatiles combustion.

Taking into account close dependences of $\mathrm{CO}_{2}$ and $\mathrm{NO}_{x}$ formation for different fuel combustion stages and essential difference between the inherent tendencies in volatile substances and coke combustion, the conclusion was made as to the necessity of separate studies of nitrogen oxides formation tendencies for the stage of coal particle volatile substances combustion and that of coke residue combustion.

\section{Nitrogen oxides formation in coke residue combustion}

In studying the combustion of coke residue, the carbon flow was calculated by the carbon weight decreasing with time. The weight decrease from the unit surface was determined by the gas analysis data taken after the volatile substances release. The calculations took into account changing the diameter of the particles burned out and the temperature of coke particles' overheating, which was as high as several hundred degrees with significant excess of air. Processing experimental data within the temperature range of 400 to $900^{\circ} \mathrm{C}$ of 
the fluidized bed enabled receiving coefficient values in the Arrhenius-type equation for the carbon oxidation speed (table 1).

Table 1: Coefficients values and activation energy in Arrhenius-type equation for speed constant of carbon and nitrogen oxidation.

\begin{tabular}{|l|c|c|c|c|c|}
\hline \multirow{2}{*}{ Parameter } & \multicolumn{5}{|c|}{ Fuels } \\
\cline { 2 - 6 } & $\begin{array}{c}\text { Moscow- } \\
\text { area coal }\end{array}$ & $\begin{array}{c}\text { Berezovsky } \\
\text { coal }\end{array}$ & Anthracite & $\begin{array}{c}\text { Coke } \\
\text { fines } \\
\text { breeze }\end{array}$ & $\begin{array}{c}\text { Kuznetsk } \\
\text { coal }\end{array}$ \\
\hline$k_{\mathrm{C}}^{0}, \mathrm{~m} / \mathrm{s}$ & 68700 & 39100 & 8700 & 8800 & 5500 \\
\hline$E_{\mathrm{N}}, \mathrm{kJ} / \mathrm{mol}$ & 135 & 131 & 118 & 113 & 107 \\
\hline $\bar{k}_{\mathrm{N}}^{0}, \mathrm{~m} / \mathrm{s}$ & 6.50 & 9.64 & 11.34 & 20.39 & 40.56 \\
\hline
\end{tabular}

A strict proportional connection is observed between the amounts of nitrogen and carbon oxides formed, which is indicative of the $\mathrm{NO}_{\mathrm{x}}$ formation intensity being dependent upon the speed of carbon combustion in the coke residue for all the coals studied. This leads one to consider the oxidation of fuel nitrogen as a heterogeneous reaction involving atomic nitrogen bound with hydrocarbons into single molecular complexes, this reaction proceeding in parallel with that of carbon oxidation. In this case, the nitrogen oxides flow $j_{\mathrm{N}}$ from the unit outer surface $\mathrm{S}$ of fuel particles can be written as follows

$$
j_{\mathrm{N}}=v_{\mathrm{N}} k_{\mathrm{N}} C_{\mathrm{O}_{2}}^{S},
$$

where $v_{\mathrm{N}}=46 / 32$ is a stoichiometric coefficient of reaction $\mathrm{N}+\mathrm{O}_{2}=\mathrm{NO}_{2} ; k_{\mathrm{N}}$ is the speed constant of nitrogen oxides formation, $\mathrm{m} / \mathrm{s} ; C_{\mathrm{O}_{2}}^{S}=\frac{C_{\mathrm{O}_{2}}}{1+k / \alpha_{\mathrm{d}}}$ is the oxygen concentration at the coke particles surface $S, \mathrm{~kg} / \mathrm{m}^{3}$, determined by the intensity of their burning out; $\alpha_{d}$ is the coefficient of diffusion mass transfer, $\mathrm{m} / \mathrm{s}$.

To calculate constant $k_{\mathrm{N}}$ by experimental data, it is necessary, at every time moment of the particle combustion, to relate its current size $\delta$ to the value of the oxygen concentration on the surface $C_{\mathrm{O}_{2}}^{S}$, which is made in solving a conventional problem of single particle burning out [6]. Since the kinetic characteristics of nitrogen oxidation $k_{\mathrm{N}}$ are involved (as well as carbon $k_{C}$ ), to calculate them accurately, it is necessary to take into account the heating temperature $T_{\text {п }}$ of burning fuel particles, which was calculated by relations given in [7].

Experimental data processing showed that the shape of the temperature dependence of the nitrogen oxidation speed constant of the fuel coke constituent by the oxygen in the air is described by the Arrhenius-type equation: 


$$
k_{\mathrm{N}}=k_{\mathrm{N}}^{0} \exp \left(-\frac{E_{\mathrm{N}}}{R T_{\mathrm{I}}}\right)
$$

where $k_{N}^{0}$ is the pre-exponential factor; $E_{\mathrm{N}}$ is the activation energy of fuel nitrogen oxidation, $\mathrm{J} / \mathrm{mol} ; R$ is the universal gas constant. By averaging the experimental values $k_{\mathrm{N}}$ at averaged activation energy $\overline{E_{\mathrm{N}}}=101507 \mathrm{~J} / \mathrm{mol}$ the values of pre-exponential factor were obtained $\overline{k_{\mathrm{N}}^{0}}$ (table 1$)$. The values of $\overline{k_{\mathrm{N}}^{0}}$, as the processing of the experimental data showed, was proportional to the nitrogen content $\mathrm{N}_{\mathrm{K}}^{\text {daf }}$ in the ashless component of the fuel coke residue.

\section{Nitrogen oxides formation in volatile substances combustion}

Suppose that the final gas-phase reaction of "volatile" nitrogen and oxygen interaction is of the first order both by nitrogen and oxygen. Assuming that $\mathrm{NO}_{x}$ formation speed is only constrained by the speed of the "volatile" nitrogen entering the fluidized bed while the oxidation reaction itself proceeds quickly enough, the expression for calculating the equilibrium constant for this reaction can be written as follows:

$$
K_{\mathrm{N}}^{0}=\frac{C_{\mathrm{NO}_{x}}}{C_{\mathrm{N}^{v o l}} C_{\mathrm{O}_{2}}} .
$$

The "volatile" nitrogen concentration can be found by:

$$
C_{\mathrm{N}^{v o l}}=\frac{d N(\tau)}{d \tau} \frac{N^{r} \varphi_{\mathrm{N}} \rho_{0}}{10000 G} V_{\mathrm{q}},
$$

where $V_{\mathrm{u}}$ is the particle volume; $\rho_{0}$ is the initial particle density; $\tau$ is the time; $\mathrm{N}^{r}$ is the nitrogen content in the fuel under operating conditions.

Values of $K_{\mathrm{N}}^{0}$ can be calculated by eqns (1)-(2) at the $\mathrm{CO}_{2}$ and $\mathrm{NO}_{x}$ concentrations specified by the experiment, depending upon the bed temperature at every time moment. As a result of the experimental data processing it was found that at the stage of volatile substances' combustion, there is dependence of the equilibrium constant $K_{\mathrm{N}}^{0}$ of the final nitrogen oxides formation reaction upon the bed temperature $T_{\text {сл }}$ of the type:

$$
K_{\mathrm{N}}^{0}=k_{\mathrm{N} V}^{0} \exp \left(-\frac{E_{\mathrm{N} V}}{R T_{\text {сл }}}\right),
$$

$k_{\mathrm{N} V}^{0}$ factor and the activation energy of the fuel nitrogen oxidation reaction by oxygen $E_{\mathrm{N} V}$, calculated by means of approximating the experimental points by the least squares method, are given in table 2 . 
Table 2: Values of elements in eqn (3) for various fuel types.

\begin{tabular}{|l|c|c|c|c|}
\hline \multirow{2}{*}{ Factor (coefficient) } & \multicolumn{2}{|c|}{ Coal } & \multicolumn{2}{c|}{ Slate } \\
\cline { 2 - 5 } & Moscow-area & Berezovsky & Estonian & Volga \\
\hline$k_{\mathrm{N} V}^{0}, \mathrm{~m}^{3} / \mathrm{kg}$ & 168.0 & 523.0 & 101.0 & 21.6 \\
\hline$E_{\mathrm{N} V}, \mathrm{~kJ} / \mathrm{mol}$ & 16870 & 30300 & 11515 & 12662 \\
\hline $\mathrm{N}^{r} \varphi_{\mathrm{N}} / 100, \%$ & 0.162 & 0.400 & 0.045 & 0.595 \\
\hline$\overline{k_{\mathrm{N} V}^{0}}, \mathrm{~m}^{3} / \mathrm{kg}$ & 90 & 47 & 110 & 20 \\
\hline
\end{tabular}

In processing the data it was found out that there was some connection between the given values of the pre-exponential factor $\overline{k_{\mathrm{N} V}^{0}}$ and the fuel nitrogen fraction (under operating conditions) released with the volatile substances $\left(\mathrm{N}^{r} \varphi_{\mathrm{N}} / 100\right)$. This dependence within the range of the nitrogen content in the fuel is reasonably approximated by a straight line, as for the fuels with a considerable $\mathrm{N}^{r}$ dispersion, it makes sense to approximate the experimental values $\overline{k_{\mathrm{N} V}^{0}}$ by the hyperbolic function of the following kind:

$$
\overline{k_{\mathrm{N} V}^{0}}=0.94\left(\mathrm{~N}^{r} \frac{\varphi_{\mathrm{N}}}{10000}\right)^{-0.667},
$$

where complex $\mathrm{N}^{r} \frac{\varphi_{\mathrm{N}}}{10000}$ is a non-dimensional value.

\section{Modeling nitrogen oxides formation in fluidized bed}

The process of nitrogen oxides formation is further discussed aimed at defining the extent of transforming the fuel nitrogen into oxides in the coke residue combustion. Changing the nitrogen oxides concentration through the height of the stationary fluidized bed as a result of the coke residue nitrogen oxidation can be expressed according to the law of effective masses for the heterogeneous reaction as the following:

$$
u d C_{\mathrm{NO}_{x}} / d h=v_{\mathrm{N}} C_{\mathrm{O}_{2}}^{s} k_{\mathrm{N}} S,
$$

where $u$ is the air speed reduced to actual conditions, $\mathrm{m} / \mathrm{s} ; h$ is the current height of the fluidized bed, $\mathrm{m}$.

Integrating dependence, eqn (4), allows obtaining the expression for calculating $\mathrm{NO}_{x}$ concentration at the bed outlet under the exponential distribution of the oxygen concentration through the bed height: 


$$
C_{\mathrm{NO}_{x}}=\mathrm{v}_{\mathrm{N}} C_{0} \frac{k_{\mathrm{N}}}{k} \frac{1}{\alpha}
$$

where $\alpha$ the excess air factor.

This expression is true only for oxidation reactions $\mathrm{C} \rightarrow \mathrm{CO}_{2}$ and $\mathrm{N} \rightarrow \mathrm{NO}_{x}$, and, taking into consideration, first, the fuel properties in terms of the ratio of nitrogen and carbon oxidation reaction speeds' constants and, secondly, the mode (state, performance) combustion parameters.

The transition fraction of the coke residue fuel nitrogen $\psi_{\mathrm{c}}$ into oxides can be expressed as:

$$
\psi_{\mathrm{c}}=\frac{14}{46} G_{\mathrm{NO}_{x}} \frac{100}{B \mathrm{~N}^{r}},
$$

where $G_{\mathrm{NO}_{x}}=\alpha V^{0} B C_{\mathrm{NO}_{x}}$ is the mass flow rate of the nitrogen oxide formed, $\mathrm{kg} / \mathrm{s} ; B$ is the fuel rate, $\mathrm{kg} / \mathrm{s} ; V^{0}$ is, in theory, the required air quantity, $\mathrm{m}^{3} / \mathrm{kg}$.

Then, based on eqn (5), the design equation for $\psi_{\mathrm{c}}$ with the coke residue combustion is received.

$$
\psi_{\mathrm{c}}=\frac{14}{32} C_{0} V^{0} \frac{k_{\mathrm{N}}}{k} \frac{100}{\mathrm{~N}^{r}} .
$$

In determining the total degree of changing fuel nitrogen into oxides in fuel combustion with considerable volatile substances' content, the average oxygen concentration in the bed is to be calculated by the equation which takes into account partial oxygen consumption spent on the volatile substances oxidation. Transforming the expression for calculating the degree of turning fuel nitrogen into oxides $\psi_{v}$ has to be made taking into account the dependence of nitrogen volatile oxides $\mathrm{NO}_{x}$ concentration formed in the combustion process upon the concentration of "volatile" nitrogen $C_{\mathrm{N}}{ }^{\text {vol }}$ and the average oxygen concentration in the bed $\bar{C}_{\mathrm{O}_{2}}$ :

$$
C_{\mathrm{NO}_{x}}=C_{\mathrm{N}^{v o l}} \bar{C}_{\mathrm{O}_{2}} \frac{K_{1}}{\left(\mathrm{~N}^{r} \varphi_{\mathrm{N}} / 10000\right)^{0.667}},
$$

where $K_{1}=0.94 \exp \left(\frac{\bar{E}_{\mathrm{N} V}}{R T}\right)$ is the complex dependent upon the bed temperature only.

In the process of fuel combustion which, hypothetically, contains combustible substances in the form of volatile ones only, the concentration $C_{\mathrm{N}}{ }^{\text {vol }}$ of fuelextracted volatile nitrogen containing substances in terms of atomic nitrogen can be calculated by the expression:

$$
C_{\mathrm{N}^{v o l}}=\frac{\mathrm{N}^{r} B}{100 G}=\frac{\mathrm{N}^{r}}{100 \alpha V_{\mathrm{J}}^{0}},
$$

where $\mathrm{G}$ is the gases flow rate, $\mathrm{m}^{3} / \mathrm{s}$. 
Given the mass flow rate of the nitrogen oxides formed $G_{\mathrm{NO}_{x}}$ being closely related to their current concentration $C_{\mathrm{NO}_{\mathrm{r}}}$ and the fuel flow rate by the equation $G_{\mathrm{NO}_{x}}=\alpha V_{\pi}^{0} B C_{\mathrm{NO}_{x}}$, the following expression is obtained:

$$
\psi_{\text {л }}=\frac{14}{46} \frac{273}{T_{\text {сл }}} \bar{C}_{\mathrm{O}_{2}} \frac{K_{1}}{\left(\mathrm{~N}^{r} \varphi_{\mathrm{N}} / 10000\right)^{0.667}} .
$$

As a first approximation, assuming that in the combined combustion of volatile substances and coke, the distribution of the oxygen concentration through the bed height is close to the exponential law, the degree of transformation is deduced:

$$
\psi_{\text {л }}=\frac{14}{46} \frac{273}{T_{\text {сл }}} \frac{C_{0} K_{1}}{\left\{(\alpha[\ln \alpha-\ln (\alpha-1)]\}\left(\mathrm{N}^{r} \varphi_{\mathrm{N}} / 10000\right)^{0.667}\right.} .
$$

where $C_{0}$ is the initial hydrogen concentration under standard conditions, $\mathrm{kg} / \mathrm{m}^{3}$.

The total transformation degree $\psi$ of the fuel nitrogen into oxides in fuel combustion supplemented by a certain release of volatile substances $V^{d a f}$ is to be written in the form of the sum with regard to the fraction $\varphi_{\mathrm{N}}$ of nitrogen oxides released with the volatiles:

$$
\psi=\psi_{\mathrm{K}}\left(1-\varphi_{\mathrm{N}} / 100\right)+\psi_{\pi} \varphi_{\mathrm{N}} / 100 .
$$

\section{Nitrogen oxides formation with oxygen deficiency}

To find out the principles of nitrogen oxides formation in the fluidized bed under the conditions of air deficiency, experiments were made to burn anthracite samples of a big weight (from 13 up to $50 \mathrm{~g}$ ), using the experimental equipment described above. The bed height was increased from 100 up to $180 \mathrm{~mm}$.

The experiments showed that increasing the sample weight had caused the relative decrease in the $\mathrm{NO}_{x}$ concentration, first, due to the deficiency of hydrogen as a reagent in $\mathrm{NO}_{x}$ formation, and, secondly, because of the oxides reduction formed on the coke surface [8-10].

Experimental data processing was done for the time period of $\mathrm{NO}_{x}$ concentrations measurement after the volatile release when the amount of $\mathrm{CO}$ in flue gases was equal to zero. It showed that the transition fraction $\psi$ of the fuel nitrogen into oxides in the anthracite particles combustion in the bed at $t 850$ $900^{\circ} \mathrm{C}$ was decreasing with the increase in the sample weight. The value of $\psi$ was calculated with regard to the experimental data.

In the coke residue combustion, as it follows from eqn (6), the value of $\psi$ does not depend upon the oxygen concentration. That is why, decreasing $\psi$ with the sample weight being increased confirms the assumption of suppressing $\mathrm{NO}_{x}$ emissions in the fluidized bed when the combustible substances concentration was increased.

Interpreting the differential equation of changing the nitrogen oxides concentration throughout the fluidized bed height allows calculating the constant value of $k_{\mathrm{NO}_{x}}^{r}$ reduction, depending upon the particle temperature. Statistic 
processing of the experimental data enabled receiving an approximated expression for it:

$$
k_{\mathrm{NO}_{x}}^{r}=1400 \exp \left[\left(-87000 / R T_{\Pi}\right)\right] .
$$

The value of activation energy in eqn (8) is close to that received in [4] in NO reduction on coke $(82 \mathrm{~kJ} / \mathrm{mol})$.

Pilot coal combustion under stationary conditions was carried out in the test furnace of the CFB, which includes a reactor of $0.14 \mathrm{~m}$ diameter and $5.6 \mathrm{~m}$ height; a cyclone of flyash removal the diameter of which is $250 \mathrm{~mm}$; a cyclone of the second stage cleaning the diameter of which is $180 \mathrm{~mm}$; a fuel supply system a flyash removal system.

The experimental data on nitrogen oxides distribution throughout the reactor height, which were obtained in various coals combustion, were used in evaluating calculations of changes in the nitrogen oxides concentration in their reduction in the overlay space of the circulating fluidized bed without taking into consideration the additional $\mathrm{NO}_{x}$ formation in it due to combustion.

In calculating the nitrogen oxides formation in the furnace with $\mathrm{CFB}$, two zones of $\mathrm{NO}_{x}$ combustion and formation will be considered: a relatively dense fluidized bed and an overlay space. In the fluidized bed itself, the nitrogen oxides concentration $C_{\mathrm{NO}_{x}}^{r e v}$ may be represented as a sum of nitrogen oxides concentrations formed from the volatile compounds and nitrogen inherent in the coke residue, this sum can be calculated by eqn (7). Decreasing the nitrogen oxides concentration in the fluidized bed itself as a result of reduction in the reaction with the carbon in the coke residue is calculated with regard to the reduction constant obtained eqn (8).

Nitrogen oxides formation as a result of the circulating coke particles combustion and their reduction by $C+\mathrm{NO}_{x}$ reaction are taken into consideration. Changing the concentration of nitrogen oxides in this case may be described by the equation (9) but taking into account the specific reacting surface $S_{\mathrm{T}}$ in the transportation zone:

$$
u \frac{d C_{\mathrm{NO}_{x}}}{d h}=v_{\mathrm{N}} k_{\mathrm{N}} C_{\mathrm{O}_{2}}^{S} S_{\mathrm{T}}-\alpha_{\mathrm{NO}_{x}}^{r} C_{\mathrm{NO}_{x}} S_{\mathrm{T}} .
$$

The initial nitrogen oxides concentration in the transportation zone is equal to that of nitrogen oxides at the bed outlet $\left(H_{\mathrm{T}}\right.$ is the transportation zone height): $H_{\mathrm{T}}=0, C_{\mathrm{NO}_{x}}=C_{\mathrm{NO}_{x}}^{\text {bed }}$. Here, the oxygen concentration on the coke particles' surface is related to the changing in height oxygen concentration in the flow in the following manner:

$$
C_{\mathrm{O}_{2}}^{S}=\frac{C_{\text {bed }}}{1+k / \alpha_{d}} \exp \left(-\frac{\alpha_{r} S_{\mathrm{f}} h}{u}\right) .
$$

Integrating eqn (9) with regard to eqn (10) enables obtaining the decrease in the concentration of nitrogen oxides formed in the fluidized bed as a result of their reduction in the overlay space. The addend describes the simultaneous nitrogen oxides formation and reduction in the flow. The results of modeling showed that the basic component in the total yield of the nitrogen oxides is 
determined by their formation in the fluidized bed. The share of nitrogen oxides formed in the overlay space does not exceed $20 \%$ of their total amount.

Calculations made using model demonstrated a fairly good correlation between calculated and experimental data.

\section{Conclusions}

1 In the solid fuels combustion in the fluidized bed, the fuel nitrogen oxides are formed both in volatile substances and coke residue burning, the concentrations of $\mathrm{NO}$ and $\mathrm{CO}_{2}$ oxides formed being proportional to each other.

2 The reactions of carbon and nitrogen oxidation occur on the surface of the coke residue particles. The quantity of the nitrogen oxides formed is proportional to the nitrogen content in the coke residue and the oxygen concentration on the surface of the particle, determined in the carbon oxidation reaction.

3 The obtained dependence of the final reaction equilibrium constant of the nitrogen oxides formation with the volatile substances being burned in the fluidized bed upon the bed temperature is fairly well consistent with the experimental data.

4 The fact of nitrogen oxides reduction on the coke particles surface has been experimentally proved, the dependence of the speed constant of the equivalent reaction of nitrogen oxides reduction on the particles' surface upon the particles' temperature was determined.

5 As a result of mathematical modeling the process of nitrogen oxides reduction in the furnace with the $\mathrm{CFB}$, an expression for calculating the changes in nitrogen oxides concentration in the furnace overlay space was obtained, using which the calculations become satisfactorily consistent with the experimental data.

\section{References}

[1] Munts,V. A., Munts,Y. G., Baskakov, A. P., Pavlyuk, E. Y. Laws of formation of nitrogen oxides from the combustion of coal and slates in a fluidized bed www.itp.nsc.ru/conferences/gtt8/files/68Munts.pdf. (Закономерности образования оксидов азота при сжигании углей и сланцев в кипящем слое/В.А. Мунц, Ю.Г. Мунц, А.П. Баскаков, Е.Ю. Павлюк // www.itp.nsc.ru/conferences/gtt8/files/68Munts.pdf.)

[2] Zel'dovich Y.B., Sadovnikov P.Y., Frank-Kamenetsky D.A. Oxidation of nitrogen during combustion. Moscow: Nauka, 1947. (Зельдович Я.Б., Садовников П.Я., Франк-Каменецкий Д.А. Окисление азота при горении. М.: Наука, 1947.)

[3] Vilensky T.V. The dynamics of the formation of nitrogen oxides from the combustion of pulverized fuel. Proceedings of the Universities. Energy. 1986. Number 12. pp. 66-70. (Виленский Т.В. Расчет динамики 
образования оксидов азота при сжигании пылевидного топлива // Изв. вузов. Энергетика. 1986. № 12. С. 66-70.)

[4] De Soete G. 23rd Intern. Symp. on Combustion. Combustion Institute, Pittsburgh, 1990. pp. 1257-1264.

[5] The combustion chemistry: translation from English. Ed. W. Gardiner. M.: Mir, 1988. (Химия горения: пер. с англ./под ред. У. Гардинера. М.: Мир, 1988.)

[6] Burning of the carbon A.S. Predvoditelev, L.N. Hitrin, O.A. Tsuhanova, et al. M., Izd - vo AN USSR, 1949. (Горение углерода/A.C. Предводителев, Л.Н. Хитрин, О.А. Цуханова и др. М.:, Л.: Изд-во АН CCCP, 1949.)

[7] Calculation of the temperature of the particles burning in a fluidized bed of inert material/A.P. Baskakov, N.F. Filippovskiy, V.A. Munts, A.A. Ashihmin. IFZh. 1987. T. 52. Рp. 788-793. (Расчет температуры частиц, горящих в кипящем слое инертного материала/А.П. Баскаков, Н.Ф. Филипповский, В.А. Мунц, А.А. Ашихмин. ИФЖ. 1987. Т. 52. С. 788-793.)

[8] Johnsson J.E., Amand L.E., Leckner B. Modelling of NOx formation in a circulating fluidized boilers // Proc. of the III Intern. Conf. on CFB. Oct. 15-18, 1990. Nagoya, Japan.

[9] Chernetzky M.Y., Gavrilov A.A., Dekterev A.A. Numerical study of pulverized coal combustion process to evaluate the effectiveness of technologies reduce nitrogen oxides. Proc. reports. VII Conf. with Int. Participation "Solid Fuel Combustion", Ch 3, Novosibirsk, 2009. (Чернецкий М.Ю., Гаврилов А.А., Дектерев А.А. Численное исследование процесса горения пылеугольного топлива для оценки эффективности технологий снижения оксидов азота // Сб. докладов. VII Bсерос. конф. с междунар. участием "Горение твердого топлива". Ч. 3, Новосибирск, 2009.)

[10] Kobylecki R., Bis Z. Emission of $\mathrm{SO}_{2}$ and $\mathrm{NOx}$ from a large-scale CFBC - effect of cyclone separation efficiency. 9th Intern. Conference on Circulating Fluidized Beds, May 13-16. 2008. Hamburg, Germany. 